\title{
A TRIAD OF PASTORAL LEADERSHIP FOR CONGREGATIONAL HEALTH AND WELL-BEING: LEADER, MANAGER AND SERVANT IN A SHARED AND EQUIPPING MINISTRY
}

Author:

Matsobane J. Manala ${ }^{1}$

\begin{abstract}
Affiliation:
${ }^{1}$ Department of Practical

Theology, University of

South Africa, South Africa
\end{abstract}

Correspondence to:

Matsobane Manala

email:

Manalmj@unisa.ac.za

Postal address:

Department of Practical

Theology, College

of Human Sciences,

University of South Africa,

PO Box 392, UNISA 0003,

South Africa

\section{Keywords:}

triad of pastoral

leadership; congregational

health and well-being;

leadership; management;

facilitation; servant

leadership

\section{Dates:}

Received: 05 Oct. 2009

Accepted: 20 Apr. 2010

Published: 13 Oct. 2010

How to cite this article: Manala, M.J., 2010, 'A triad of pastoral leadership for congregational health and well-being: Leader, manager and servant in a shared and equipping ministry', HTS Teologiese Studies/Theological Studies 66(2), Art. \#875, 6 pages.

DOI: 10.4102/hts.v66i2.875

This article is available at:

http://www.hts.org.za

\section{INTRODUCTION}

This article discusses the work, function and role of the pastor as a triad. The term 'triad' means 'a group of three people or things that are related or similar to each other' (Longman Dictionary of Contemporary English 2001:1543). In the context of this article the concept 'triad' refers to the threefold facilitating responsibilities of the pastor. The pastor is viewed as having leadership, management and service provision facilitation responsibilities within a shared and equipping ministry (cf. Ogden 1990:179). Ogden (1990:179) describes the pastor as 'head of staff' and as 'first among equals'; that is he or she is co-leader, manager and servant, along with the other people of God. It is suggested that efficient and effective facilitation of this threefold task is the key to congregational health and well-being, that is, to the state of a well functioning congregation in terms of the fulfilment of its God-given purpose. As Steve Mills (adapted from Crowe 2001) indicates:

A healthy church functions as the body of Christ. Most of those who attend are in unity with Christ and in harmony with each other as a community of faith while intentionally pursuing God's purposes in culturally and contextually appropriate ways. This is expressed in four dimensions. First, they hold to right doctrine and truth and maintain spiritual passion. Second, they build loving holistic relationships combined with functional structures for effective ministry. Third, they demonstrate biblically appropriate roles, respect, and relationships between the pastor(s) and church leaders. Fourth, each individual walks in vibrant growing faith with God and others.

(Mills 2009:1)

A healthy church thus functions in terms of its building and maintenance of inter- and intrarelationships, adhering to sound doctrine, practical task fulfilment and spiritual nurturing and growth. A dysfunctional congregation, on the other hand, fails dismally in the abovementioned critical areas of church life and work, as Steve Mills (adapted from Crowe 2001) points out:

A dysfunctional church is one in which many of those who attend are not in unity with Christ or in harmony with each other. They generally are not intentionally pursuing God's purposes. If they are, they are not expressing them in culturally or contextually appropriate ways in a balanced manner. Often they identify themselves as Christians who are sincere with good intentions of practicing biblical principles. But they are continually conflicted with combinations of imbalance or erroneous doctrine, fads, irresponsibility, incompetent or dysfunctional leadership, controversial government, and disciplinary problems. This results in strife, division, turmoil, ineffective ministry, wounded and confused people, and a negative reputation in the community.

(Mills 2009:1)

The critical areas of church and congregational unity, harmony, sound doctrine, responsibility, discipline, competence in ministry, efficient and effective leadership and holistic Christian healing and spiritual health and growth are greatly compromised in a dysfunctional church, negatively affecting its efficient performance of its task.

Facilitation of strong leadership, prudent management and dedicated and committed service are required for the church to remain the dynamic life-giving body of Christ. The church, unlike a business concern, is a voluntary organisation. There is no guaranteed availability of workers for the implementation of goals. The pastor is often the only paid employee whose availability for church work is guaranteed, except on very rare occasions. As such, the pastor is rightly trusted with church leadership, management and service facilitation. He or she is the person in whom ultimate responsibility resides, notwithstanding the acknowledged mutual responsibility in the organic team ministry (cf. Ogden 1990:180).
(C) 2010. The Authors. Licensee: OpenJournals Publishing. This work is licensed under the Creative Commons Attribution License. 
Stephens (2001) points to Nehemiah as an example par excellence of the servant-leader-manager dynamic, rightly stating:

He performed roles of: convincing functionaries of the worth and feasibility of the envisaged operation, delegating work to people with appointed supervisors, coordinating the work and setting goals based on the glory of God and people's needs.

(Stephens 2001:7)

This article acknowledges the pastor's facilitation of the threefold task, as shown above, and which I subsequently discuss using a literary study of relevant sources.

\section{THE PASTOR AS A CHRISTIAN LEADER}

A Christian leader operates within the faith community in accordance with God's call. The Christian leader's call is 'always from God for a specific God-given purpose. There is no place for the leader's own agenda' (Bishop 1995:60; see also Blackaby \& Blackaby 2001:14). God's call and its contents therefore determine the focus of the Christian leader's activities (cf. Bishop 1995:62). God therefore gives, through the work of the Holy Spirit, vision and authority to Christian leaders for the benefit of the church as their people, as well as for all humanity (cf. Buchanan 1995:78; Storey 1995:69). Christian leadership is, therefore, as Stevens and Collins (1993:109) rightly posit:

[T] he God-given ability to influence others so that believers will trust and respond to the Head of the church for themselves, in order to accomplish the Lord's purposes for God's people in the world.

(Stevens \& Collins 1993:109)

In many church traditions, the pastor is accepted as the leader (cf. Church Order of the Maranatha Reformed Church of Christ 2006:4, article 3, section xv; cf. Kyrie Eleison 2008, in respect of the United Methodist Church in Western Kentucky). Pattison (1977:57), too, describes the pastor as the symbolic representative of Christ. He points out that the church as a living system has the pastor as its leader (see also Ogden 1990:179). As a leader, the pastor is expected to perform to the best of his or her abilities, leadership functions and roles in the context of, and in cooperation with, the faith community. The task of the leader in the systems approach is equipping members of the system to function effectively in order to grow and achieve their common collective goals. Pattison (1977:69) presents the below-mentioned seven important leadership functions that are performed with the aim of equipping the saints.

\section{The symbolising function}

Christ is, according to the Bible, the only head of the church identified with the body of Christ. This identification suggests that the church is a living system or organism. Richardson (1996:28) states: 'The system is the total of all the members and their different actions and reactions'. Every living system has an identity, which is expressed through shared values and goals. These values and goals are embodied in symbols that serve as the constant standard of reference. By virtue of his or her pastoral office, the pastor is a major symbol of the church system; one which points to the head of the whole body: Jesus, the Lord and centre of the system. Church leadership should therefore always be Christocentric.

The pastor must provide a continuing affirmation of the group identity, its purposes, its values and its goals. He or she does not tell the system what its identity is, but rather recall for the system what the system has created. In effect, the pastor says: 'Let me refresh our memories - we agreed to come together and commit ourselves to ...' (Pattison 1977:63). The pastor calls the system to self-awareness.

\section{The being function}

With this function, the pastor affirms the individual identity, rather than the group identity, by affirming themselves to be a unique person, thereby affirming each individual member of the system as a unique person. In this function, the pastor needs to acknowledge that he or she is a mortal being who is liable to make mistakes and should thus never pretend to be capable of solving every problem. He or she should therefore not present themselves as individuals who are complete and perfect, but rather as one member with assets and limitations and, moreover, as one who can and will contribute to the whole. By so doing, the pastor will be liberating others as well themselves. All members of the system, including the pastor, should strive to be themselves and contribute from their limited resources. For the leader to accept limited humanity enables others towards similar self-acceptance (cf. Pattison 1977:64).

\section{The sharing function}

As a part of the system, the pastor has much to share with the system. Firstly, the pastor must share his or her narcissism, that is, their excessive love of, and interest in, self, giving up the desire to be always on centre stage and the chief benefactor of the rewards. All achievements of the system must be seen to be the result of all system members' efforts and not of the pastor's alone. In an effectively functioning system, it is unwarranted for the pastor to take personal credit for congregational achievements. He or she should rather give credit to the system, thus empowering church members. Pattison (1977:65) writes: '...the father who potentiates his children may receive no direct recognition, but in the end have the satisfaction of seeing his children succeed'

Secondly, the pastor must share responsibility. If the pastor takes and holds on to all responsibilities, the church or the system will not act responsibly. Thirdly, the pastor must share authority. Responsibility goes hand-in-hand with authority, for when people are given responsibility, they must be given some authority to take necessary decisions as well.

Fourthly, as leader of the system, the pastor must also share control. The leader who attempts to control everything actually controls nothing. Church control is consented to by the church as a system and the pastor who carries the whole burden of responsibility-authority-control is open to stress and crisis. Such a pastor deprives the system of the potential to embrace growth with both hands and will therefore remain immature. The wisdom of Jethro (Ex 18:17-23) is quite significant in this regard. Sharing his or her humanity, responsibility, authority and control reveals that the leader trusts members of the system, thus enhancing the members' self-trust. Such an approach is quite useful for it activates and energises members of the system towards responsibility and service. In that context of broader involvement, the myth of the 'great man' leadership is dealt a deadly blow and the truth of Bennis and Biederman's (1997:1) words, 'None of us is as smart as all of us' [my emphasis] is affirmed. It is clear from these words that the community of leadership, made of leaders and members, functions better than the individual super human leadership in the promotion of congregational health and well-being.

The pastor should also share his or her God-given vision for the church. If people have no idea of the anticipated outcome of any activity, they will not be enthused to work as required. The pastor thus has to inspire and share with members of the body of Christ. Kouzes and Posner (2004:16) write: 'Leaders inspire a shared vision. They envision the future, and they enlist others in a common vision'. Unless they do this, the body or system will not easily understand the dynamics of, or be convinced to follow, their leader's vision.

\section{The intentionality function}

According to Pattison (1977:66), effective leaders do not work in an ad hoc way. They plan and work intentionally, following 
particular decisions, directions and methods. The intentionality function points to the maintenance of conscious intentions, whereby the leader prioritises different tasks that are all competing for attention. This function helps preclude pointless complaints, frustration and powerlessness. The intentionality function ensures that one's leadership of a system forms a unity that is coherent in its basic identity, defined intentions and shared consciousness. By behaving intentionally, the pastor potentiates similar behaviour by members of the system and, as a result, the system will function in more guided and purposeful ways.

\section{The modelling and risk-taking function}

The leader should give clear instructions and model the preferred ways of doing what needs to be done. The church as a living system can only function more effectively if its leader communicates clearly, both verbally and through body language. Modelling or setting an example is a strong motivation to the group. Kouzes and Posner (2004) articulate this truth well: 'The most powerful thing a leader can do to mobilize others is to set the example by aligning personal actions with shared values'. Explaining further, they say:

Leaders are measured by the consistency of their deeds and words by walking the talk. Leaders show up, pay attention and participate directly in the process of getting extraordinary things done.

(Kouzes \& Posner 2004:12)

Pattison (1977:67) identifies two maxims which apply to the modelling and risk-taking function of the leader in the context of a living system. These are, (1) do not ask people to do what you have not done first or are not willing to do and (2) do not ask people to do something without offering yourself as a trial model. As Kouzes and Posner (2004:11) rightly argue: 'When you are leading a group or an organization, you have to move from "what I believe" to "what we believe". A leader must stick his or her neck out. Explaining further, Pattison (1977) says:

By modelling of course I do not mean offering a perfect examplefar from it! Rather, I mean providing a clear definition of what you are asking, and then giving them an example of how it might be done-you offer yourself as an example. You say, in effect: 'Look, here is what we want to do. I do not know precisely how to do it. But I would try it this way. Criticise my attempt. See where I fail. Then see if you can improve upon it'.

(Pattison 1977:67)

This modelling involves risk. The leader takes the first step, opening themselves to possible criticism. Such modelling and risk-taking represents the leader's preparedness to offer themselves as a model of willingness to experiment. Such action activates other members of the system towards doing what is required with enthusiasm and without fear.

\section{The limit-setting function}

There are no superhuman beings, neither are there perfect human systems. Human depravity is also expressed in the systems and can turn them into destructive instruments. This points to the limitations that exist within individual and group functioning. As leader of a living system, the pastor should keep a continual watch over the functioning of the church and of each individual member. Neither member nor leader should be compromised and destroyed in the functioning of the system. To prevent this from happening in the church, the pastor must identify limits and encourage others to recognise and respect them.

Such limits should not be viewed as punishment, but rather as the necessary establishment of boundaries of acceptable action or behaviour. Setting limits also implies maintaining those boundaries so that members must bear the consequences of their actions. Setting limits should be viewed in a more positive light. 'Discipline' provides a suitable representation of the limit-setting function of a leader in the church context. As such,
Pattison (1977) states:

It implies a consistent demand for and reinforcement of right actions and a refusal to accept or tolerate wrong actions ... Thus the pastor, in the limit-setting function, must consistently reinforce the healthy behaviour of the system and restrain the system from destructive action.

(Pattison 1977:69)

\section{The catalytic and enabling function}

Although all the seven leadership functions can rightly be summed up under this function, there are some specific tasks that fall under this rubric and demand some attention. The first is the task of connector. The connecting task brings different subsystems together to enable them to collaborate towards the accomplishment of their common goals. Under this rubric, the pastor has the task of fostering collaboration, which is, in the words of Monte Campbell (Kouzes \& Posner 2004:28), 'the master skill that enables teams, partnerships and other alliances to function effectively, so leaders foster collaboration by promoting collaborative goals' [author's emphasis].

The second task is that of mediator, which involves conflict resolution, the establishment of priorities and the ordering of activities. The third task is that of facilitator. Facilitating involves the task of planning and organising subsystems which activate their effective functioning. The final task is that of the catalyst, of which Pattison (1977) writes:

The term catalyst is borrowed from the process of chemical reactions. You can mix chemical ingredients but get no reaction until you add just a pinch of the right catalyst to trigger the reaction. The catalyst overcomes the initial resistance and once the chemical reaction is underway it proceeds from its own energy.

(Pattison 1977:69)

The pastor is expected to and must supply that pinch of energy to break the initial resistance and thereby enable the system to engage in interactions that will generate their own momentum. Played efficiently, these roles engender and enable systems' health, growth and compassion.

Congregational health and well-being requires not only efficient church leadership but also prudent church management. Church management is quite important, especially since it refers to stewardship of God's household. Van der Ven (cited in Wolfaardt 2001:4) rightly states: '... without management there is no building of the Spirit, no body of Christ and no church as Jesus' movement or as people of God. Without management, there is no community of believers' (see also Pattison 2000:286287). The pastor is looked upon to facilitate church management as well. Below is a discussion of a pastor's role in church management facilitation.

\section{THE PASTOR AS A CHURCH MANAGER}

Stephens (2001:21) refers to the symbiotic relation between management and leadership and appropriately notes: 'Sometimes the same person, a person such as the pastor, wears both hats'. Shawchuck and Heuser (1996:21) argue that the pastor also becomes God's steward, a word of which the original meanings are similar to those of the Greek word for manager, oikonomos, (which gives us the word 'economist'). Oikonomos originates from two Greek words, oikos, meaning 'house' and nemein, meaning 'dispense' or 'manage' (Stott 1988:20) and thus refers to the house manager and steward to the guardian of the hall. Stott (1988) further notes:

The manager of a household or of household affairs; especially steward, manager, superintendent ... to whom the head of a house or proprietor has entrusted the management of his [sic] affairs, the care of receipts and expenditures and the duty of dealing out the proper portion to every servant and even to the children not yet of age.

(Stott 1988:20; cf. Mellody \& Theron 2006:112) 
The responsibility of the pastor as manager is to see to the orderly and just functioning of God's affairs.

I am perturbed by some authors' uncritical acceptance of the definition of management as: 'getting things done through other people' as Wolfaardt (2001:5) points out. I have a niggling feeling that this cannot be appropriate with regard to church management as it smacks of the objectification of people. In my opinion, a more sensitive definition should read: church management is a process and act of planning, organising, evaluating and facilitating efficient and effective functioning towards the achievement of ecclesial goals through effective utilisation of time, physical, financial and other relevant resources in meaningful collaboration with other people. Wan's (2009) definition, which I find agreeable, is that '... management in Christian circles is basically stewardship of the talents of the persons entrusted to our care'. Utilising people's talents and not people themselves should be the objective of effective church management. Mellody and Theron (2006:105) indicate that the style of church management must, unlike that of secular management, be persuasive rather than commanding and its foundation must be the love and justice found in Christ.

According to Swanepoel (2000:30) the goal of management is to get the work done as efficiently and effectively as possible (i.e. systematically and accurately). In the words of Drucker (cited in Wolfaardt 2001:5), the aim of management is 'the improvement of organisational performance', for which the following five basic elements are required, (1) setting objectives and determining what needs to be done to attain these objectives, (2) organising the work that needs doing into an organisational structure with manageable activities and jobs, (3) motivating and communicating with teams of people and using decisions on pay, promotion and placement to ensure that the teams work efficiently, (4) measuring performance with the aid of established targets and yardsticks and (5) developing people, including themselves (i.e. managers) (cf. also Pattison 2000:285)

The pastor is expected to facilitate fulfilment of the four management functions, namely planning, organising, leading and directing (as discussed below), efficiently and effectively for the realisation of church health and well-being.

\section{Planning}

Planning is the key to all management functions and needs to be the foundation on which the other functions build in order to not allow the church to degenerate into chaos and failure. Indeed, planning one's work and working one's plan is the key to success. It is obvious therefore, that failing to plan is, unwittingly, planning to fail.

To facilitate prudent planning, the pastor has to consider the current state of the congregation and its desired future. Planning in church management includes setting congregational objectives, developing policies and programming, establishing procedures, scheduling and budgeting. The planning process never stops - it is ongoing and pastors and other church leaders must be aware of this. Rane (2007) calls this ongoing planning function, which is the result of continued evaluation and reevaluation, 'strategic management'. Here the pastor analyses internal and external factors that are capable of affecting the congregation positively or negatively, as well as goals and objectives. Such analysis enables the pastor to determine the church's strengths, weaknesses, opportunities and threats and to re-plan accordingly. Important questions in the planning function, according to McGraw-Hill (2009), are: 'Which goals should be pursued? How should the goals be attained? How should resources be allocated?' The correct answers to these questions bring planners closer to efficient and effective performance.

\section{Organising}

Organising is another management function necessary for congregational health and well-being and entails resource organising and allocation. It includes developing internal organisational structures and organising them for the efficient and effective implementation of plans and for delegating establishing and maintaining interpersonal relationships, which are essential to well-being of staff in an organisation. Mutual respect and reciprocity are important when people work together. The principles of 'ubuntu', which are, (1) morality, (2) interdependence, (3) the spirit of humankind and (4) totality, could advance the needed harmonious collaboration (cf. Mbigi \& Maree 1995:88-90)

Organising also entails grouping people into departments according to their talents and the tasks that they need to perform. In church management this means having and preparing task groups that include the lay members for service. In terms of collaboration with other persons, it is desirable that certain requirements will come into consideration. Certain knowledge, skills, values, talents and charismas (special gifts of the Spirit) will have to be taken into account in task allocation. Some degree of authority, power, responsibility and accountability needs to be given to people as well.

\section{Leading}

Another important management function is leading. The pastor also facilitates the fulfilment by God's people of their leadership responsibilities. Leading involves decision-making, communicating, developing people, directing them in their tasks and motivating them to properly carry them out. Leading and directing in management are also used interchangeably and through this function pastors are able to influence and oversee staff behaviour as they strive to achieve set goals. Managers are able to influence the staff through motivation, communication, group dynamics, leadership and discipline.

Effective communication is vital in maintaining a productive working community and environment, in building positive interpersonal relationships and for solving problems effectively. Understanding the communication process and working on areas that need improvement help managers to become more effective communicators. The best way to find areas that need improvement is, according to Rane (2007), to periodically ask oneself and others how well they are doing.

Leading has to do with vision, the effective use of the power of persuasion with a view to sufficient motivation and commitment of functionaries. McGraw-Hill (2009) rightly states that the following three points are of particular importance:

- In leading, managers determine direction, state a clear vision for employees to follow, and help employees understand the role they play in attaining goals.

- Leadership involves manager using power, influence, vision, persuasion and communication skills.

- The outcome of the leading function is high level of motivation and commitment from employees to the organization.

(McGraw-Hill 2009)

Such interaction between the pastor and church members promotes interdependence and efficient performance. Members are thus persuaded and enabled to enthusiastically pursue God's purposes.

\section{Controlling}

Management also involves controlling or evaluating, which involves establishing performance standards, performance measuring, actual performance evaluating, reporting and performance correcting. The controlling function 'ensures that the tasks being carried out drive the organisation towards 
achieving its goals' (Mellody \& Theron 2006:116). It enquires into whether the organisation is moving in the right direction and doing the right things correctly. According to McGraw-Hill (2009):

- In controlling managers evaluate how well the organisation is achieving its goal and take corrective action to improve performance.

- Managers will monitor individuals, departments and the organisation to determine if desired performance has been reached.

- Managers will also take action to increase performance as required.

- The outcome of the controlling function is the accurate measurement of performance and regulation of efficiency and effectiveness.

(McGraw-Hill 2009)

The pastor is placed in the caretaker position. Stewards facilitate performance of the four managerial functions in support of church tasks of kerygma (proclaiming), martyria (witnessing), koinonia (fellowship), diakonia (service), didaché (instruction) and leitourgia (worship). Managerial functions are carried out through the performance of managerial roles at various congregational levels. The three broad managerial role categories listed by McGraw-Hill (2009) that I consider as relevant for the pastor as well are: interpersonal, informational and decisional roles. These roles will not, however, be discussed here because of lack of space and the fact that the core contents of the roles have featured briefly in the above discussion.

\section{THE PASTOR AS A SERVANT LEADER}

The central assumption here is that the pastor is, and must act as, a servant. Servant leadership is a unique leadership style that 'is characterised by the desire to serve and empower followers' (Wong 2003:1). Bennet Sims (1997) describes servant leadership as:

[A] way of life [that] aims to co-create with God a just, nonviolent and sustainable habitat for all that lives. Servant leaders exist less for themselves than for others. They work for the transformation of human systems and for a finer world.

(Sims 1997)

In Archbishop Emeritus Desmond Tutu's (2006:1) lecture entitled 'Real leadership', he highlights attributes that are central to servant leadership: integrity, humility, altruism, and so forth. Servant leadership is thus considered real leadership.

Patterson (cited in Waddell 2006:2) defines servant leaders as 'those leaders who lead an organization by focusing on their followers, such that the followers are the primary concern and the organizational concerns are peripheral'. Servant leadership thus focuses on service provision for the promotion of followers' development, growth, health, independence, interdependence and survival. True servant leadership has to lead to others' growth, health, wisdom, freedom, autonomy and servanthood. It should benefit the least privileged in society. According to Patterson (cited in Waddell 2006:2), servant leaders are guided by the following seven principles, which propose that a leader should, (1) demonstrate agape love, (2) act with humility, (3) be altruistic, (4) be visionary for their followers, (5) be trusting, (6) empower their followers and (7) serve.

As one who is expected to continue the work of Jesus of Nazareth, the pastor should likewise be servant of all (Mt 20:26-28; Mk 10:43-45). What the pastor must be and do is to be a servant first and then a leader (cf. Greenleaf 1970). Greenleaf (1970) continues:

It begins with the natural feeling that one wants to serve. Then conscious choice brings one to aspire to lead. The difference manifests itself in the care taken by the servant - first to make sure that other people's highest priority needs are served.

(Greenleaf 1970; cf. also Spears 2004)
The leadership style inherent in servant leadership is what Stevens and Collins (1993:68) call 'total involvement'. For Jesus, greatness or effectiveness or honour of leadership resides in serving rather than being served. For the Christian pastor, service provision is, therefore, importantly the call and command of Jesus to his disciples - past and present. For a Christian pastor, serving is therefore a matter of faith, obedience and following the Christian lifestyle.

Servant leadership ushers in a fresh critical look at the issues of power and authority and gives people an opportunity to learn, through the experience of servant leadership practice, to relate in more supportive rather than coercive ways (cf. Greenleaf 2002:81). New standards apply here, as Winslow (1995) points out:

...in the kingdom or structures of the world, the standard is really, how much power do I have? How many people do I control? And how much money do I make?' Those are the bases for any future advance. In the Lord's kingdom, however, the criterion is, how much service can I give?

(Winslow 1995:10)

As a servant leader, the pastor has a crucial role to play in challenging the conventional hierarchical and domineering view of leadership through love, humility, altruism, being visionary for followers, trust and commitment to service. This will not only build and empower their followers but will also teach the followers to demand servant leadership both in the church and society. Such leadership also has the potential to influence positively church life and work, political, as well as community leaders, and life (cf. Barbuto \& Wheeler 2007:1). Under the servant leadership, the dysfunctional church will more likely be healed and transformed and be able to liberate and transform congregants and communities. According to Watson (2009) the role of the pastor servant leader should be: to equip the faith community and to love and live harmoniously with others. The pastor should be a champion of evangelism and of the task of building up the congregation (cf. also Stevens \& Collins 1993:116-117)

In short, then, the important principles of servant leadership which I consider significant are the following, as derived from Ogden (1990):

- People in the highest positions of authority have the greatest obligation to serve.

- Servant leadership is rooted in relationship, not coercion.

- Servant leadership naturally seeks to support, not to control.

- Servant leaders shine the spotlight of recognition on those with whom they share leadership.

- Servant leaders are embarrassed by titles and the trappings of status.

- Servant leaders' authority is recognised on the basis of their character in Christ, not on the position or office that is held.

(Ogden 1990:176)

Christ's command to his disciples (Mk 10:43) and Peter's advice to his fellow elders (1 Pt 5:3) to not lord it over those placed in their care and to be examples in terms of servanthood and moral behaviour, are clearly articulated in the abovementioned servant leadership principles.

\section{CONCLUSION}

This article has shown that the pastor's threefold facilitation task does not imply a monopoly of control over the church, but is meant to enable, through various functions and roles, other parts of the system to achieve collective congregational goals. The triad of pastoral leadership fosters unity with Christ, the head of the church, and harmony among members as a faith community. It diffuses strife, division, turmoil, ineffective ministry, hurt, confusion and a negative reputation in the community through the equipping of all members for service. Situated within the systems approach, pastoral leadership, as 
described in this article, is about life - congregational life - and life is never simply an event, but rather a process. In this type of broad-based leadership within the congregation as a living system, the pastor's leadership style is the total involvement style which is high on both relationship and task performance (cf. Stevens \& Collins 1993:68). It is not about power but service; not for the leader's self-interests but for God's interests; not by own authority but by God's calling and authority.

\section{REFERENCES}

Barbuto, J.E. \& Wheeler, D.W., 2007, Becoming a servant leader: Do you have what it takes?, viewed 16 May 2010, from http:// www.lasallian.org.au/public/resources/fetch.cfm?fid=4D9A77EA

Bennis, W. \& Biederman, P.W., 1997, Organizing genius: The secrets of creative collaboration, Addison-Wesley, Reading, MA.

Bishop, C., 1995, 'A leader's call', in D. Buchanan \& J. Hendriks (eds.), Meeting the future: Christian leadership in South Africa, pp. 60-68, Knowledge Resources, Randburg.

Blackaby, H. \& Blackaby, R., 2001, Spiritual leadership: Moving people on to God's agenda, Struik Christian Books, Cape Town.

Buchanan, D., 1995, 'A leader's authority', in D. Buchanan \& J. Hendriks (eds.), Meeting the future: Christian leadership in South Africa, pp. 78-88, Knowledge Resources, Randburg.

Buchanan, D. \& Hendriks, J. (eds.), 1995, Meeting the future: Christian leadership in South Africa, Knowledge Resources, Randburg.

Greenleaf, R.K., 1970, 'Who is the servant-leader?', The Newsletter of The R.K. Greenleaf Center for Servant-Leadership 57, p. 2.

Greenleaf, R.K., 2002, 'The servant as leader', Excerpts from Servant Leadership, The Robert Greenleaf Center, Indianapolis, IN.

Kouzes, J.M. \& Posner, B.Z. (eds.), 2004, 'The five practices of exemplary leadership', in Christian reflections on the leadership challenge, Jossey-Bass, San Francisco, CA.

Kyrie Eleison, 2008, Pastor as spiritual leader, viewed 28 March 2009, from http://revdsky.blogspot.com/2008/08/pastor-asspiritual-leader-part-i.html

Longman Dictionary of Contemporary English, 2001, 'Triad', Edinburgh, Harlow Essex.

Maranatha Reformed Church of Christ, 2006, 'Church Order' 2006, unpublished, Pretoria.

Mbigi, L. \& Maree, J., 1995, Ubuntu: The spirit of African transformation management, Knowledge Resources, Randburg.

McGraw-Hill, I., 2009, The four functions of management, viewed 23 January 2009, from http://www.csupomona.edu/ wcweber/301/301slide/ch01301/sld006.htm

Mills, S., 2009, Intentionally building a healthy church: The General Council of the Assemblies of God, viewed 18 February 2009, from http://webuildpeople.ag.org/wbp_library-/0004_ intentionallybuilding.cfm

Ogden, G., 1990, The new Reformation: Returning the ministry to the people of God, Zondervan, Grand Rapids, MI.

Pattison, E.M., 1977, Pastor and parish, Fortress, Philadelphia, PA.
Pattison, S. 2000, 'Management and pastoral theology', in J. Woodward \& S. Pattison (eds.), The Blackwell reader in pastoral and practical theology, pp. 283-293, Blackwell, Oxford.

Rane, S., 2007, 'The four functions of management: Foundation of all management concepts', Business and Finances, 12 September 2007, viewed 23 January 2010, from http://www. associatedcontent.com/article/373994/the_four_functions of_management_foundation.html?cat=3

Richardson, R.W., 1996, Creating a healthier church: Family systems theory, leadership and congregational life, Fortress, Minneapolis, MN.

Shawchuck, N. \& Heuser, R., 1996, Managing the congregation: Building effective systems to serve people, Abingdon, Nashville, TN.

Sims, B., 1997, What is servant leadership?, viewed 15 April 2009, from http://www.servantleader.org/reflections. html

Spears, L., 2004, 'The functions of a servant-leader', Leader to Leader 34, 7-11.

Stephens, G.A., 2001, Management and leadership for the African Church, viewed 14 December 2009, from www. africanadvance.org

Stevens, R.P. \& Collins, P., 1993, The equipping pastor: A systems approach to congregational leadership, The Alban Institute, New York, NY.

Storey, P., 1995, 'A leader's vision', in D. Buchanan \& J. Hendriks (eds.), Meeting the future: Christian leadership in South Africa, pp. 69-77, Knowledge Resources, Randburg.

Stott, J.R.W., 1988, The preacher's portrait: Some New Testament word studies, Eerdmans, Grand Rapids, MI.

Swanepoel, F., 2000, Church management: A basic workbook on planning, administration, management and financial management, University of South Africa, Pretoria.

Wan, T.Y., 2009, Church management seminar, viewed 19 January 2009, from http//:www.thamwan.org

The Greenleaf Center for Servant Leadership, 1977, What is servant leadership?, viewed 28 April 2009, from http://www. greenleaf.org/whatissl/

Tutu, M.D., 2006, 'Real leadership', Harold Wolpe Memorial Trust Tenth Anniversary Memorial Lecture, 23 August 2006, The Whale Well, Iziko South, Cape Town.

Waddell, J.T., 2006, 'Servant leadership', Servant Leadership Research Roundtable - August 2006, viewed 31 March 2010, from http://www.regent.edu/acad/global/publications/ sl_proceedings/2006/waddell.pdf

Watson, D., 2009, 'Leadership essentials - Pastoral leadership vs. priesthood of believers', viewed 02 April 2009, from http://www.davidlwatson.org/2009/04/02/leadershipessentials-\%E2\%80\%93-pastoral-leadership-vs-priesthoodof-believers/

Winslow, P., 1995, 'Leadership in the church: Mark 10:35-45', Discovery Publishing Catalog, No. 3624

Wolfaardt, J.A., 2001, 'Practical Theology: Congregational management', unpublished study guide CGM308-3, University of South Africa, Pretoria.

Wong, T.P., 2003, 'An opponent-process model of servant leadership and a typology of leadership styles', unpublished paper presented at the Servant Leadership Roundtable, 16 October 2003, Regent University, Virginia. 